\title{
Tratamientos de consolidación e hidrofugación aplicados a sustratos graníticos húmedos y contaminados por sales solubles
}

\section{Consolidating and water repellent treatments applied to wet and salt contaminated granite}

Fecha de recepción: 19-1-99

B. SILVA, T. RIVAS y B. PRIETO

Fecha de aceptación: 21-III-99

ESPAÑA

\section{RESUMEN}

Se analiza la eficacia de dos consolidantes y dos hidrofugantes aplicados a rocas graniticas en condiciones óptimas comparativamente a la eficacia de los mismos productos aplicados sobre los mismos sustratos conteniendo cierta cantidad de sales solubles o de agua. Se compara la cantidad de producto absorbido y la cantidad de materia seca presente tras el curado. Los resultados indican que la presencia de agua y de sales solubles en la piedra modifica significativamente el consumo de los productos, sobre todo el de los hidrofugantes, así como la cantidad de materia seca. Se observa, asimismo, un fuerte detrimento en la eficacia de los hidrofugantes cuando el sustrato contiene sales mientras que, al contrario, la presencia de agua no parece influir en dicha eficacia. La falta de correlación entre el consumo, materia seca activa y eficacia lleva a concluir que la presencia de sales o agua modifica sensiblemente la cinética de la polimeración de los productos.

\section{SUMMARY}

A comparison was made of the efficacy of two consolidants and two water repellents applied to samples of granite under optimum conditions, with the efficacy of the same products applied to the granite in the presence of soluble salts or water. The amount of product absorbed and the amount of dry polymer remaining after treatment were compared. The results show that the presence of water and soluble salts in the stone significantly modifies the consumption of the products (in particular the water repellents) and also the level of dry polymer retained. The water repellents were found to be much less effective when the substrate contained salts, whereas the presence of water did not appear to influence their efficacy. The lack of correlation between uptake, active dry polymer, and efficacy led to the conclusion that the presence of salts or water markedly changes the kinetics of the polymerization of the products.

\section{INTRODUCCIÓN}

El comportamiento de las rocas graníticas en los edificios y los factores involucrados en su deterioro son aspectos que se han empezado a investigar desde hace un tiempo relativamente corto, si bien se ha avanzado mucho en su conocimiento, siendo hoy en día

\section{INTRODUCTION}

The behaviour of granite in buildings and the factors involved in its deterioration have only recently begun to be investigated, nevertheless, knowledge has advanced greatly in the past few years so that, at present the subject is fairly well documented (Casal 
bastante conocidos (Casal et al., 1989; Delgado, 1989; Silva et al., 1996 a; Silva et al., 1996 b; Rivas, 1997). No ocurre así con los aspectos relacionados con la problemática de su conservación: existen muy pocos trabajos de investigación dedicados específicamente a rocas graníticas ya que en los países pioneros en estos estudios, las rocas usadas en la construcción son otras y las particularidades del granito, como su carácter polimineral y su porosidad de tipo fisural, hacen imposible extrapolar a ellas resultados obtenidos para otros tipos rocosos.

Actualmente se está produciendo un incremento significativo de intervenciones de conservación, sobre todo hidrofugación y consolidación, en el Patrimonio Monumental gallego, construido casi en su totalidad con rocas graníticas. Este hecho suscita la necesidad de realizar estudios acerca de la eficacia de productos de tratamiento con el objetivo de poder sentar las bases de conocimiento necesarias para acometer con criterio científico dichas intervenciones.

Por otra parte, cuando se acomete el tratamiento de los monumentos no siempre éstos se encuentran en condiciones adecuadas y es conocido que la hidrofugación y consolidación de la piedra puede ser, en estos casos, contraproducente. No es infrecuente que se proceda a hidrofugar un edificio recién construido o recién rehabilitado conteniendo todavía humedad de obra. También, la aplicación de este tipo de tratamientos en edificios, ya sea recién construidos o no, en los cuales la piedra posea cierto contenido de sales solubles, puede ser origen de futuras lesiones.

El conseguir un secado completo de la roca en los edificios antes de una intervención y más todavía, desalinizar la piedra, suponen en la mayoría de los casos un inconveniente insalvable. Por esta razón, muchos de los productos destinados a este tipo de intervenciones están preparados para su uso en condiciones no idóneas; sin embargo, no existen estudios rigurosos que evalúen los efectos de la aplicación sobre sustratos en este estado, y más todavía, cuando se trata de sustratos graníticos. Este hecho nos ha llevado a realizar este estudio cuyo propósito es conocer el efecto de la aplicación de productos de consolidación e hidrofugación sobre sustratos graníticos con cierto contenido de agua o de sales solubles y su eficacia en estas condiciones.

El estudio se ha realizado con dos rocas graníticas ampliamente utilizadas en la construcción de edificios en Galicia y los productos ensayados son dos consolidantes a base de silicato de etilo y dos hidrofugantes de tipo polisiloxano, productos muy usados en las intervenciones actuales sobre el Patrimonio Monumental Construido en Galicia. et al., 1989; Delgado, 1989 ; Silva et al., 1996 a; Rivas et al., 1996 b; Rivas, 1997). This is not the case with aspects concerning the problem of their conservation and there exist very few studies that specifically investigate granite, as in the countries pioneering these studies, other kinds of stone are used in the construction of buildings. The peculiarities of granite (such as its polymineral character and its fissural type of porosity) make it impossible to extrapolate results obtained for different kinds of stone to granite.

There has recently been a significant increase in the amount of conservation work being carried out, in particular using water repellent and consolidation treatments, in Galician historical buildings and monuments which are constructed almost entirely from granite. Thus investigation of the efficacy of these products is necessary in order to be able to select, using scientific criteria, the most appropriate treatments for this kind of work.

However, when conservation work is undertaken, the buildings involved are not always in suitable conditions and it is known that use of water repellents and consolidants on stone can be counterproductive in these cases. It is not uncommon to find when applying a water repellent to a recently constructed or restored building that the construction work has not yet dried. Application of this kind of treatment to buildings, whether recently constructed or not, where the stone contains a certain amount of soluble salts, may lead to deterioration of the stone in the future.

To try to obtain completely dry surfaces on buildings before carrying out conservation work, and in addition to desalinate the stone would, in most cases be totally unrealistic. Many of the products used in this kind of work, are designed for use in non ideal conditions. However there have been no rigorous studies evaluating the effect of their application to substrates (and even less involving granite) under these conditions. Thus, we have carried out the present study with the aim of finding out the effect of the application of consolidating and water repellent treatments to granitic substrates in the presence of water or soluble salts, and their efficacy under these conditions.

The study was carried out with two granitic rocks, widely used in the construction of buildings in Galicia. The products tested were two ethyl-silicate based consolidants and two polysiloxane water repellents both commonly used in current conservation projects involving Galician Historical Buildings and Monuments. 


\section{MATERIAL Y MÉTODOS}

\section{Rocas seleccionadas}

El primer granito se denomina Baleante (B) y procede del Monte Baleante, en la península del Barbanza; al NW de Galicia. Es una roca que está siendo actualmente muy utilizada en la construcción de edificios en Santiago de Compostela ya que posee un aspecto muy similar a la roca granítica que constituye el material de construcción del casco antiguo de esta ciudad.

El segundo granito se denomina Axeitos $(\mathrm{AX})$ y procede del lugar del mismo nombre, en el Municipio de Riveira, al Sur de la Península del Barbanza. Es una roca de coloración rojiza y constituye el material de construcción de un importante monumento megalítico gallego (Dolmen de Axeitos) y de la arquitectura popular de la zona.

La descripción de estas rocas desde el punto de vista mineralógico, petrográfico y fisico puede consultarse en Rivas et al. (1998). En la Tabla 1 se presentan, resumidos, algunos aspectos característicos de ambos granitos.

\section{Productos aplicados}

Como consolidantes, se han aplicado Tegovakon $\mathrm{V}$ (Goldschmidt) y Consolidante OH (Silicem-Wacker).

\section{MATERIALS AND METHODS}

\section{Granites used}

The granites used in the study were Baleante (B) granite and Axeitos (AX) granite. Baleante (B) granite, is quarried from Monte Baleante on the Barbanza Peninsula (NW Galicia). It is currently widely used in the construction of buildings in Santiago de Compostela as it is very similar in appearance to the granite used in the historical part of the city.

Axeitos (AX) granite is quarried from Axietos (Riveira) on the south of the Barbanza Peninsula. It is reddish in colour and is the material which was used in the construction of an important Galician megalithic monument (the Axeitos dolmen) and other buildings in the region.

A description of the mineralogical, petrographical and physical characteristics of these rocks is given by Rivas et al. (1998). A summary of some of these characteristics is shown in Table 1.

\section{Products tested}

The consolidants tested were, Tegovakon $V$ (Goldschmidt) and Consolidant OH (Silicem-Wacker).

TABLA 1 (TABLE 1)

Granulometría y tipo de fisuración mayoritaria observada bajo miscroscopía óptica de fluorescencia de los dos granitos Baleante (B) y Axeitos (AX). Se presentan también los valores de porosidad accesible al agua (\%) y el contenido de agua en saturación (\%) determinados según RILEM, 1980.

(Granulometry and main type of fissuration seen with fluorescent microscopy in Baleante (B) and Axeitos (AX) granites. Values for open porosity (\%) and water saturation content (\%), determined according to RILEM (1980), are also shown).

\begin{tabular}{||c|c|c||}
\hline & $\mathbf{B}$ & $\mathbf{A X}$ \\
\hline $\begin{array}{c}\text { Granulometría } \\
\text { (Granulometry) }\end{array}$ & $\begin{array}{c}\text { Media } \\
\text { (Medium) }\end{array}$ & $\begin{array}{c}\text { Medio-gruesa } \\
\text { (Medium-coarse) }\end{array}$ \\
\hline $\begin{array}{c}\text { Tipo de Fisuración mayoritaria } \\
\text { (Main type of fissuration) }\end{array}$ & $\begin{array}{c}\text { Intra e intergranular } \\
\text { (Intra and } \\
\text { intergranular) }\end{array}$ & $\begin{array}{c}\text { Transgranular } \\
\text { (Transgranular) }\end{array}$ \\
\hline $\begin{array}{c}\text { Porosidad accesible (\%) } \\
\text { (Open porosity (\%\%)) }\end{array}$ & 2,84 & 2,06 \\
\hline $\begin{array}{c}\text { Contenido de agua en saturacion (\%) } \\
\text { (Water saturation content (\%)) }\end{array}$ & 1,11 & 0,80 \\
\hline
\end{tabular}


Ambos son etilésteres del ácido silícico que en contacto con el agua molecular presente en la piedra reaccionan formando sílice y etanol. Las características de ambos productos se presentan en la Tabla 2 .

Como hidrofugantes, se han aplicado Siliker S-101 (Silicem-Wacker) y Tegosivin Hl-100 (Goldscmidt). Sus características se exponen en la Tabla 2.

\section{Aplicación en condiciones óptimas de intervención}

En el caso de la consolidación, se utilizaron dieciséis probetas de cada granito de dimensiones $5 \times 5 \times 5 \mathrm{~cm}$, lavadas con agua destilada y secas hasta peso constante. Ocho probetas de cada granito se sumergieron totalmente durante 24 horas en cada uno de los productos. Pasado este tiempo, se extrajeron las probetas de los productos y se determinó, por diferencia de peso, la cantidad de producto absorbido (expresado como consumo en $\mathrm{g} / \mathrm{m}^{2}$ ) y tras 30 días de polimerización a temperatura ambiente se determinó la cantidad de materia seca o polimerizada, expresada en $\mathrm{g} / \mathrm{m}^{2}$.
Both are ethyl-esters of silicic acid which on contact with water molecules present in the stone react to form silica and ethanol. The characteristics of both products are shown in Table 2.

The water repellents under investigation were, Siliker $S$ 101 (Silicem-Wacker) and Tegosivin HI-100(Goldschmidt). Characteristics of these products are shown in Table 2.

\section{Application of treatment under optimum conditions}

To test the consolidants, 16 samples $(5 \times 5 \times 5 \mathrm{~cm}$ cubes) of each granite were first washed with distilled water and dried to a constant weight. Eight of the test samples of each granite were totally submerged for 24 hours in each of the two products under test. The samples were then removed and the amount of product absorbed was determined by the difference in weight of the samples before and after treatment. Samples were then left for a period of 30 days at ambient temperature to allow polymerization to take place and the amount of dry or polymerized material was then determined by the weight gain of the samples. Both amount of product absorbed, and amount of dry material were expressed as $\mathrm{g} / \mathrm{m}^{2}$

TABLA 2 (TABLE 2)

Especificaciones suministradas por los fabricantes de los productos ensayados. TG: Tegovakon-V; C-OH:

Consolidante OH; TS: Tegosivin H1-100; SK: Siliker S-101. -: dato no aportado.

(Manufacturers specifications for the products under test. TG: Tegovakon-V; S-OH: Consolidant OH; TS: Tegosivin HI-100; SK: Siliker S-101. -: data not given).

\begin{tabular}{|c|c|c|c|c|}
\hline & TG & $\mathrm{C}-\mathrm{OH}$ & TS & SK \\
\hline $\begin{array}{l}\text { Composición } \\
\text { (Composition) }\end{array}$ & $\begin{array}{l}\text { Etil silicato } \\
\text { (Ethyl silicate) }\end{array}$ & $\begin{array}{l}\text { Etil silicato } \\
\text { (Ethyl silicate) }\end{array}$ & $\begin{array}{c}\text { Etilmetoxisiloxano } \\
\text { (Ethyl- } \\
\text { methoxysiloxane) }\end{array}$ & $\begin{array}{l}\text { Organo siloxano } \\
\text { (Organo siloxane) }\end{array}$ \\
\hline Disolvente (Solvent) & Etanol (Ethanol) & Etanol (Ethanol) & ---- & --- \\
\hline $\begin{array}{l}\text { Compuestos orgánicos } \\
\text { (Organic compounds) }\end{array}$ & $>75 \%$ & $>75 \%$ & $100 \%$ & --- \\
\hline Densidad a $25^{\circ} \mathrm{C}$ (Density at $25^{\circ} \mathrm{C}$ ) & $0,95 \mathrm{~g} / \mathrm{c} . \mathrm{c}$. & $0,94 \mathrm{~g} / \mathrm{c} . \mathrm{c}$. & $0,80 \mathrm{~g} / \mathrm{c} . \mathrm{c}$. & $1,12 \mathrm{~g} / \mathrm{c} . \mathrm{c}$. \\
\hline $\begin{array}{l}\text { Color } \\
\text { (Colour) }\end{array}$ & $\begin{array}{c}\text { Incoloro } \\
\text { (Colourless) }\end{array}$ & $\begin{array}{c}\text { Incoloro } \\
\text { (Colourless) }\end{array}$ & $\begin{array}{c}\text { Incoloro } \\
\text { (Colouriess) }\end{array}$ & $\begin{array}{c}\text { Incoloro } \\
\text { (Colourless) } \\
\end{array}$ \\
\hline Punto de Inflamación (Flashpoint) & $13^{\circ} \mathrm{C}$ & --- & ---- & $32{ }^{\circ} \mathrm{C}$ \\
\hline Viscosidad (Viscosity) & - & $212 \mathrm{~s}$ & $120-300 \mathrm{cst}$ & --- \\
\hline Aplicación (Application) & Directa (Direct) & Directa (Direct) & Diluido (Diluted) & Directa (Direct) \\
\hline $\begin{array}{l}\text { Tiempo de polimerización } \\
\text { (Time of polymerizatión) }\end{array}$ & $\begin{array}{l}2 \text { semanas } \\
(2 \text { weeks })\end{array}$ & $\begin{array}{l}2 \text { semanas } \\
(2 \text { weeks })\end{array}$ & $\begin{array}{c}8 \text { días } \\
(8 \text { days })\end{array}$ & $\begin{array}{l}36 \text { horas } \\
(36 \text { hours })\end{array}$ \\
\hline $\begin{array}{l}\text { Consumo recomendado } \\
\text { (Recomended uptake) }\end{array}$ & $0,5-1,5 \mathrm{l} / \mathrm{m}^{2}$ & $0,5-1,51 / \mathrm{m}^{2}$ & $0,5-1,51 / \mathrm{m}^{2}$ & $0,1-21 / \mathrm{m}^{2}$ \\
\hline
\end{tabular}


En el caso de los hidrofugantes, el método de aplicación, basado en Ferreira (1993), ha consistido en la inmersión parcial de las probetas de dimensiones $5 \times 5 \times 5 \mathrm{~cm}$. Los productos se vierten en un recipiente que se coloca sobre una balanza y se procede a la inmersión de las probetas hasta una profundidad de $1 \mathrm{~cm}$ durante 30 segundos. Después de este tiempo, se retira la probeta del hidrofugante, se deja escurrir el producto sobrante durante 10 segundos con la cara tratada hacia abajo, tras lo cual se gira la probeta y se almacena con la cara tratada hacia arriba.

La cantidad de producto absorbido (expresado como consumo) se determinó por la diferencia de peso tras los 10 segundos de escurrido y la materia seca, se determinó por la diferencia de peso tras 30 días de curado. Cada producto se aplicó en 5 probetas de cada granito.

\section{Aplicación en condiciones no idóneas de intervención}

\section{Aplicación en sustratos con cierto contenido de agua}

Para obtener un contenido fijo y conocido de agua, seis probetas de cada granito $(5 \times 5 \times 5 \mathrm{~cm})$ se saturaron en agua destilada (tras aproximadamente 15 días de inmersión total) y después se dejaron secar a $20^{\circ} \mathrm{C}$ y $70 \%$ de humedad relativa hasta conseguir un contenido de agua de un $50 \%$ en peso respecto al de saturación, que se alcanza aproximadamente tras 2-3 horas de secado. En este momento, se aplicaron los productos consolidantes e hidrofugantes por los métodos descritos anteriormente. Cada producto de tratamiento se aplicó en tres probetas por granito.

\section{Aplicación en sustratos con cierto contenido en sales šolubles}

Se ha escogido como sal soluble el sulfato de sodio, debido a que es una de las sales involucradas en el desarrollo de las formas de deterioro más graves que afectan a las rocas graníticas en los edificios en Galicia (Silva et al., 1996 b).

Doce probetas de cada granito secas a peso constante y de porosidad accesible conocida se sometieron a cinco ciclos de cristalización de sulfato de sodio según el ensayo RILEM (1978).

Tras estos ciclos, las probetas se cepillaron suavemente para eliminar las posibles eflorescencias salinas y, sin lavarlas, se aplicaron los productos de tratamiento, utilizando tres probetas de cada granito
To test the water repellents, the application method was based on that of Ferreira (1993) which involves partial immersion of the granite. Samples of granite $(5 \times 5 \times 5 \mathrm{~cm}$ cubes) were weighed and then immersed in the test solution to a depth of $1 \mathrm{~cm}$, for $30 \mathrm{~s}$. After drip-drying over the solution for 10s, the blocks were turned over, reweighed and stored with the treated surface upwards.

The amount of product absorbed (expressed as uptake) was determined by the weight gain of the granite cube from before immersion to after drip drying. The sample was reweighed after 30 days to determine the amount of dry polymer retained - calculated as the difference in weight of the granite before treatment and after 30 days. Each product was applied to 5 granite samples.

\section{Application of treatment under non ideal conditions}

\section{Application to wet substrates}

In order to work with a known amount of water, six samples of each granite $(5 \times 5 \times 5 \mathrm{~cm}$ cubes) were saturated with distilled water by immersing for approx. 15 days. The samples were then dried at 20 ${ }^{\circ} \mathrm{C}$ and a relative humidity of $70 \%$, until the water content was $50 \%$ of that at saturation. This usually took 2-3 hours. The consolidants and water repellents were then applied using the methods described above. Each treatment was applied to three samples of each granite.

\section{Application to substrates in the presence of soluble salts}

The salt chosen for use was sodium sulphate as this is one of the salts implicated in the worst cases of deterioration of granite in Galician buildings (Silva et al., 1996 b).

Twelve samples of each granite dried to a constant weight and of known open porosity were subjected to five cycles of crystallization with sodium sulphate following the method outline in RILEM (1978).

The samples were then lightly brushed to remove any possible saline efflorescens and, without washing, the treatment products were applied to three samples of each granite following the methods already 
para cada producto, siguiendo los métodos descritos anteriormente. Sobre probetas de control que fueron sometidas igualmente a los mismos ciclos de cristalización de sulfato de sodio se realizó un análisis del contenido de sales solubles. Para ello, un gramo de muestra extraida de cada probeta control y molido hasta un tamaño menor de $1 \mathrm{~mm}$ se agitó en $100 \mathrm{ml}$ de agua desionizada. Tras dos horas de agitación se filtró el extracto y en él se determinó el contenido de aniones por electroforesis capilar y de cationes por espectroscopía de absorción y emisión atómica. En la Tabla 3 se presenta el valor medio de los contenidos de diferentes iones correspondientes a tres probetas control de cada granito.

\section{Medida de la eficacia}

Se determinó la porosidad accesible al agua en las probetas antes de tratar y después de ser tratadas tanto en condiciones idóneas como en presencia de sulfato de sodio y de agua y la eficacia de los consolidantes se estimó a partir de la disminución de la porosidad producida por los tratamientos.

Para medir la eficacia de los hidrofugantes se determinó, antes y después del tratamiento, el ángulo de contacto roca-agua, siguiendo el método propuesto por Ferreira (1993). Para la determinación de este parámetro, se coloca la probeta de forma que la cara del ensayo (que corresponde a aquélla que será tratada con el hidrofugante) esté totalmente horizontal y coincidente con la base de un micrómetro existente en uno de los oculares de una lupa.

Se deja caer una microgota de cuatro microlitros de described. Control samples which were subjected to the same crystallization procedures, were analysed for soluble salt content. For this, $1 \mathrm{~g}$ samples were taken from each control cube of granite, ground to $<1 \mathrm{~mm}$ and shaken in $100 \mathrm{ml}$ distilled water. After $2 \mathrm{~h}$ of shaking, the extract was then filtered, the anion content determined by capillary electrophoresis, and the cation content by atomic absorption and emission spectophotometry. The mean contents of the different ions in three control samples of each granite are shown in Table 3.

\section{Evaluation of efficacy}

The open porosity was determined in the samples before and after treating, in ideal conditions as well as in the presence of sodium sulphate or of water. The efficacy of the consolidants was estimated from the decrease in porosity produced by the treatments.

To evaluate the efficacy of the water repellents, the rock-water contact angle before and after treatment was determined, following the method proposed by Ferreira (1993). To determine this parameter, the sample was placed level, with the test surface (i.e the treated surface) focussed in line with a micrometer in one of the eyepieces of a stereo microscope.

A $4 \mu \mathrm{l}$ microdroplet of distilled water was allowed to

TABLA 3 (TABLE 3)

Contenido de los diferentes iones en (mg/100 g) de los granitos Axeitos y Baleante sometidos a cinco ciclos de alteración artificial con sulfato de sodio (RILEM, 1978). Los valores son las medias de los obtenidos en tres probetas de cada granito.

(Content of different ions as ( $\mathrm{mg} / 100 \mathrm{~g}$ ) in Axeitos and Baleante granite subjected to 5 cycles of artificial weathering with sodium sulphate (RILEM, 1978). Values are means from three samples of each granite).

\begin{tabular}{|c|c|c||}
\hline & AXEITOS & BALEANTE \\
\hline $\mathrm{Na}^{+}$ & 0,38 & 0,39 \\
$\mathrm{~K}^{+}$ & $7,10-3$ & 0,01 \\
$\mathrm{Mg}^{2+}$ & $5,10-4$ & $4,10-4$ \\
$\mathrm{Ca}^{2+}$ & 0,01 & 0,01 \\
$\mathrm{Cl}^{-}$ & 0,01 & 0,01 \\
$\mathrm{SO}_{4}{ }^{--}$ & 0,19 & 0,29 \\
$\mathrm{NO}_{3}^{-}$ & 0,01 & $5,10-3$ \\
$\mathrm{HCO}_{3}^{-}$ & 0,02 & 0,06 \\
\hline
\end{tabular}


agua destilada desde una pipeta alejada de la superficie de la probeta $10 \mathrm{~mm}$. Se ajusta el enfoque de la lupa para obtener el perfil de la gota siempre a una ampliación de 10 aumentos. Se realiza la medición con el micrómetro de la dimensión de la base de la gota (a) y de la altura (h). El ángulo de contacto roca-agua se determina a partir de la expresión fall from a pipette at a height of $10 \mathrm{~mm}$ from the sample surface. The focus was adjusted so that the outline of the droplet was always magnified $x 10$. Measurements of the area of the base (a) and the height (h) of the droplet were made using the micrometer. The rock-water contact angle was calculated using the equation:

$$
\left(^{\circ}\right)=2 \operatorname{arctg}(2 \mathrm{~h} / \mathrm{a})
$$

Para cada superficie de medida se determinó el ángulo de contacto de 10 microgotas.

\section{RESULTADOS}

\section{Resultados de la consolidación}

\section{Consumo de los productos}

En la Tabla 4 y Figura 1 se presentan los valores de consumo y de materia seca de los productos consolidantes aplicados en condiciones óptimas y en presencia de agua y de sulfato de sodio.
For each sample, the contact angles of 10 microdroplets were determined.

\section{RESULTS}

\section{Results of application of consolidants}

\section{Uptake of products}

Values of the parameters measured to evaluate uptake of consolidants after application under optimum conditions and in the presence of water and sodium sulphate are shown in Table 4 and Figure 1, as is the amount of dry polymer remaining in the rock.

\section{TABLA 4 (TABLA 4)}

Consumo (C: $\mathrm{g} / \mathrm{m}^{2}$ ), cantidad de Materia Seca activa (MS: $\mathrm{g} / \mathrm{m}^{2}$ ) y relación Consumo/Materia Seca (C/MS) en la consolidación de Axeitos (AX) y Baleante (B) con sulfato de sodio, saturadas en agua en un $50 \%$ y tras el tratamiento en condiciones óptimas

(Uptake (U: $\left.\mathrm{g} / \mathrm{m}^{2}\right)$, amount of active Dry Polymer (DP: $\left.\mathrm{m} / \mathrm{g}^{2}\right)$ and ratio of Uptake/Dry Polymer (U/DP) after consolidation in Axeitos $(A X)$ and Baleante $(B)$ granites, in the presence of sodium sulphate, $50 \%$ saturation with water, and after treatment under optimum conditions).

\begin{tabular}{||c|c|c|c|c|c|c||}
\hline & \multicolumn{3}{|c|}{$\begin{array}{c}\text { CONSOLIDANTE OH } \\
\text { (CONSOLIDANT OH) }\end{array}$} & \multicolumn{3}{c|}{ TEGOVAKON } \\
(TEGOVAKON)
\end{tabular}



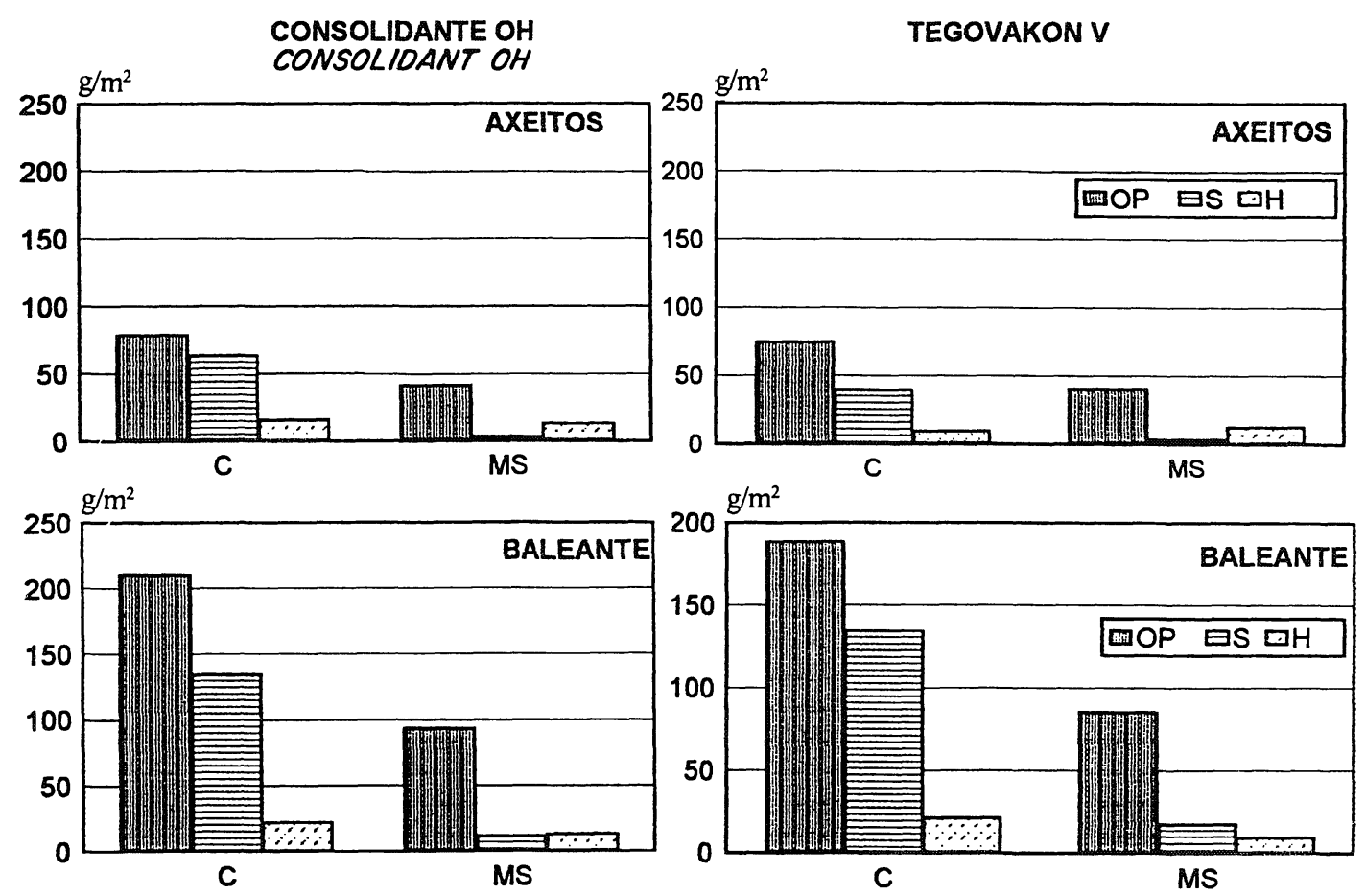

Figura 1.- Consumo y cantidad de materia seca activa en las muestras de Axeitos (AX) y Baleante (B) consolidados en óptimas condiciones (OP), en presencia de sulfato de sodio (S) y en presencia de agua (H).

Figure 1.- Uptake and amount of active dry polymer in the samples of Axeitos $(A X)$ and Baleante (B) granites after consolidation treatment under optimum conditions (OP), in the presence of sodium sulphate (S) and in the presence of water (H).

En condiciones óptimas de aplicación el consumo de ambos productos es más elevado en el granito más poroso, Baleante. Sin embargo, teniendo en cuenta la relación consumo / materia seca, existe más cantidad de materia seca en el granito Axeitos, lo que puede interpretarse como que la relación de polimerización ha sido, en principio, más eficaz, permaneciendo en la roca más cantidad de producto. Tegovakon presenta en ambos granitos una relación consumo/materia seca más baja que Consolidante $\mathrm{OH}$ lo que implica una mayor eficacią en la reacción de curado de este producto.

En presencia de sulfato de sodio, el consumo de ambos productos desciende comparativamente al tratamiento en óptimas condiciones: AX absorbió un 18\% menos de Consolidante $\mathrm{OH}$ y un $46 \%$ menos de Tegovakon $\mathrm{y}$ Baleante absorbió un 36\% menos de Consolidante $\mathrm{OH}$ y un $28 \%$ menos de Tegovakon. La cantidad de materia seca en estas muestras se ve, asimismo, reducida, encontrándose cantidades excesivamente bajas que responden a un descenso con respecto al tratamiento en óptimas condiciones de un 79-90\%. La relación consumo/materia seca tan elevada puede indicar que la materia activa de los productos (es decir, el monómero aplicado) ha sido desplazada hacia la superficie de la roca por el disolvente durante el secado, de manera que
Under optimum conditions, uptake of consolidants was greatest in the most porous granite (Baleante). However, the amount of dry polymer remaining in the rock was highest in the Axeitos granite which, taking into consideration the relation between uptake and amount of dry polymer may mean that the the polymerization reaction was, at least initially, more efficient. In both granites the ratio of uptakel dry polymer was lower for Tegovakon than for Consolidant $O H$, suggesting that the polymerization process was more efficient in Tegovakon.

In the presence of sodium sulphate, the uptake of both products was lower than with application under optimum conditions: AX absorbed 18\% less of Consolidant $O H$ and $46 \%$ less Tegovakon, and Baleante absorbed $36 \%$ less of Consolidant $\mathrm{OH}$ and $28 \%$ less Tegovakon. The amount of dry polymer remaining in these samples was thus reduced to extremely low values, there being a decrease of 79-90\% compared to treatment under optimum conditions. The high ratio of uptake/dry polymer may indicate that the active material in the products (i.e. the monomer applied) has been displaced to the surface of the rock by the solvent during the drying process so that there was no deposition of the 
no ha habido reacción ni deposición de consolidante en el interior de la masa rocosa. En estas muestras, vuelve a ser Tegovakon el producto que en ambos granitos muestra una relación consumo/materia seca más baja.

En presencia de humedad, el consumo de ambos productos se ve reducido con respecto al tratamiento en óptimas condiciones en mayor medida que en presencia de sulfato de sodio. Axeitos consume, con respecto al tratamiento normal, un $80 \%$ menos de Consolidante $\mathrm{OH}$ y un $86 \%$ menos de Tegovakon. Baleante consume un $88-90 \%$ menos de ambos productos. Sin embargo, la relación consumo/materia seca de ambos productos y en ambos granitos es inferior a la obtenida en el tratamiento en condiciones idóneas, es decir, la cantidad de materia seca con respecto al consumo en estas muestras es más elevada que en las tratadas en óptimas condiciones. En Axeitos, el producto que aparece en mayor cantidad de materia seca con respecto al consumo es Tegovakon y en Baleante es Consolidante $\mathrm{OH}$.

\section{Eficacia de los consolidantes}

En la Figura 2 se representa la porosidad de los granitos antes de tratar, tratados en condiciones óptimas de aplicación y tratados en presencia de sulfato de sodio y de agua.

En el tratamiento en óptimas condiciones, el producto más eficaz en la reducción de la porosidad en el granito de Axeitos es Tegovakon y en Baleante es Consolidante $\mathrm{OH}$. El porcentaje de reducción de la porosidad en AX es de un 7\% para el tratamiento con Consolidante $\mathrm{OH}$ y de un $13 \%$ para el tratamiento con Tegovakon. En Baleante, Consolidante $\mathrm{OH}$ reduce la porosidad en un $21 \%$ y Tegovakon lo hace en un $16 \%$. product within the structure of the stone. Tegovakon was once more the product that had the lowest ratio of uptake/dry polymer (in both granites).

The presence of water affected the uptake of both products, reducing it to a greater extent than the presence of sodium sulphate. Axeitos granite absorbed $80 \%$ less of Consolidant $\mathrm{OH}$ and $86 \%$ less Tegovakon than under optimum conditions. Baleante absorbed $88-90 \%$ less of both products. However, the ratio of uptake/dry material of the products in both granites was less than under optimum conditions, that is, the amount of dry polymer retained compared to that absorbed by these samples was higher than with treatment under optimum conditions. Axeitos granite retained relatively more Tegovakon, and Baleante granite retained relatively more of Consolidant $\mathrm{OH}$.

\section{Efficacy of consolidants}

The porosities of the granites before treatment, after treatment under optimum conditions and after treatment in the presence of sodium sulphate and of water are shown in Figure 2.

Under optimum conditions, the product which was most efficient in reducing the porosity in Axeitos granite was Tegovakon and in Baleante it was Consolidant $\mathrm{OH}$. Consolidant $\mathrm{OH}$ reduced the porosity of $A X$ by 7\%, while Tegovakon reduced it by 13\%. In Baleante granite, Consolidant $\mathrm{OH}$ reduced the porosity by $21 \%$, and Tegovakon by $16 \%$.
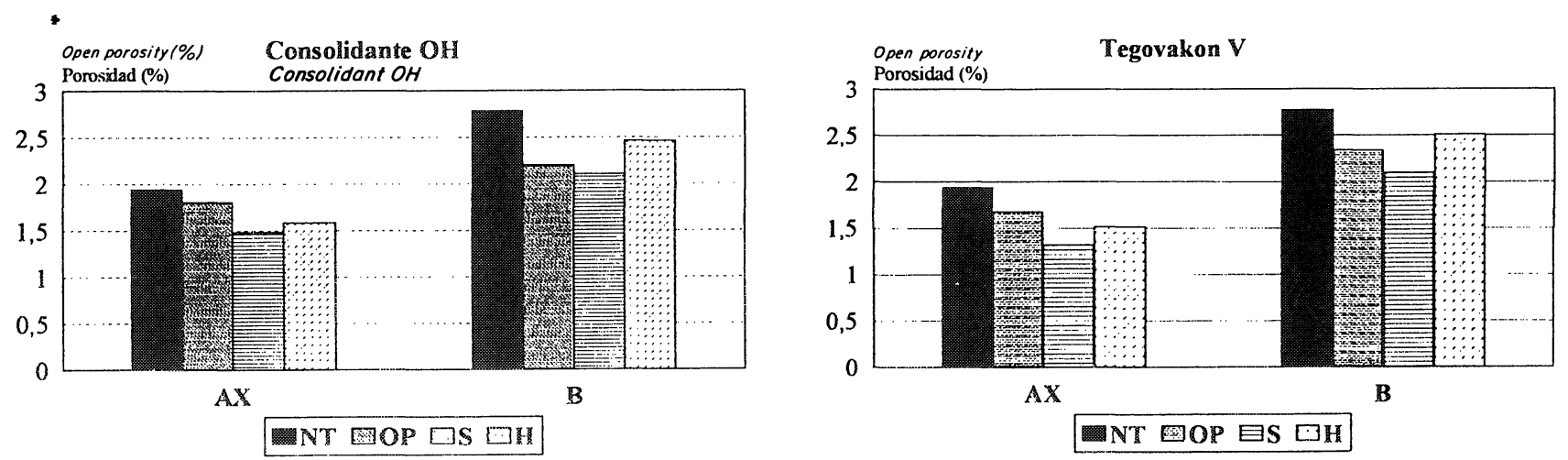

Figura 2.. Porosidad de Axeitos (AX) y Baleante (B) no tratado (NT), tratados con Consolidante OH (izquierda) y Tegovakon V (derecha) en condiciones óptimas (OP), en presencia de sulfato de sodio $(\mathrm{S})$ y en presencia de agia $(\mathrm{H})$.

Figure 2.- Porosity of Axeitos (AX) and Baleante (b) whithout treatment (NT), treated with Consolidant OH (left) and Tegovakon (right) under optimum conditions $(O P)$, in the presence of sodium sulphate $(S)$ and in the presence of water $(H)$. 
En el caso de Axeitos, la mayor eficacia de Tegovakon expresada en base a la reducción en la porosidad está de acuerdo con la mayor cantidad de materia seca presente en estas muestras, pero no así en el caso de Baleante en el que también es este mismo producto el que presenta una mayor cantidad de materia seca con respecto al consumo.

En las muestras tratadas conteniendo sulfato de sodio, la porosidad se reduce con el tratamiento en una proporción mayor que las muestras tratadas en condiciones óptimas. En Axeitos, Tegovakon reduce la porosidad en un 29\%y Consolidante $\mathrm{OH}$ lo hace en un $25 \%$. En Baleante, Tegovakon reduce la porosidad en un $25 \%$, mientras que la porosidad de las muestras tratadas con Consolidante $\mathrm{OH}$ es similar a la porosidad de las muestras tratadas con el mismo producto en condiciones óptimas.

El hecho de que en estas muestras se obtengan valores de materia seca notablemente inferiores a las obtenidas en el tratamiento en condiciones óptimas indica que la reducción de la porosidad puede ser debida más que a una eficacia real, a la presencia de la sal en el interior de los poros de las rocas, que provoca que el valor de porosidad accesible medido sea inferior al real.

En presencia de humedad, Axeitos tratado con ambos consolidantes presenta una porosidad inferior a la obtenida en el tratamiento en óptimas condiciones: Consolidante $\mathrm{OH}$ reduce la porosidad en un $21 \%$ y Tegovakon en un $23 \%$. En estas muestras, la mayor eficacia en la reducción de la porosidad está de acuerdo con los valores de materia seca, los cuales son también más altos, a juzgar por las relaciones consumo/materia seca, que los correspondientes al tratamiento en condiciones idóneas. Asimismo, el consolidante Tegovakon, que es el que reduce en un mayor porcentaje la porosidad es también, de los dos productos, el que aparece en mayor cantidad como materia seca. Estos hechos indican que, en principio, la presencia de agua en el granito de Axeitos no ha impedido una correcta polimerización de los productos en la roca.

En las muestras de Baleante tratadas en presencia de agua, la eficacia de los productos en base a la reducción de la porosidad es inferior a la correspondiente al tratamiento en óptimas condiciones. En el caso de las muestras tratadas con Tegovakon, esta menor eficacia viene acompañada por un valor de materia seca con respecto al consumo menor que el correspondiente al tratamiento en condiciones óptimas; sin embargo, en el caso de las muestras tratadas con Consolidante OH existe más cantidad de materia seca que en el tratamiento en condiciones idóneas. Esto no cieja de ser llamativo
The effectiveness of Tegovakon in terms of the reduction in porosity of the AX granite corresponded with the greater amount of dry polymer retained in these samples. However, this was not the case with the Baleante granite where application of Tegovakon also resulted in a relatively high level of dry polymer retained but without a proportional reduction in porosity.

In the test samples containing sodium sulphate, the porosity was reduced to a greater extent than in the samples treated under optimum conditions. The porosity of the AX granite was reduced by $29 \%$ using Tegovakon and by $25 \%$ with Consolidant $\mathrm{OH}$. In the Baleante granite Tegovakon reduced the porosity by $25 \%$, while the reduction after application of Consolidant $\mathrm{OH}$ was similar to when this product was used under optimum conditions.

The values obtained for the amount of dry polymer retained were notably less in these samples than when the treatment was under optimum conditions. This indicates that, rather than being truly effective, the reduction in porosity was due to the presence of salts in the pores of the stone which led to the value measured for open porosity being less than the real value.

In the presence of water, the porosity of Axeitos granite treated with both consolidants was less than that obtained under optimun conditions. Consolidant $\mathrm{OH}$ reduced porosity by $21 \%$ and Tegovakon by $23 \%$. In these samples, the greater effectiveness in reducing the porosity was in accordance with the levels of dry polymer retained - also higher (judging by the ratio of uptake/dry polymer) than the corresponding values after treatment under optimum conditions. Thus Tegovakon, which was the product that led to the greatest reduction in porosity, was also that which was retained to the greatest extent as dry polymer. These facts show that the presence of water in the Axeitos granite did not impede the polymerization process.

In the Baleante granite treated in the presence of water, the efficacy of the products in terms of reduction in porosity, was less than that of the corresponding treatments under optimum conditions. For Tegovakon, the lower effectiveness was accompanied by a lower value of dry polymer retained (in terms of that absorbed) than with treatment under optimum conditions. However, in the samples treated with Consolidant $O H$ there was a greater amount of dry polymer retained than under optimum conditions. This result is surprising as a greater amount of dry polymer retained should imply greater effectiveness. One possible 
puesto que una mayor cantidad de materia seca implicaría una mayor eficacia. Una posible explicación puede ser que, si bien la materia activa ha penetrado en la roca y ha permanecido en ella tras el curado, la reacción de polimerización no se ha llevado a cabo de manera que, al no formarse el polímero, los poros no han sido tapizados de una manera suficiente para reducir la porosidad.

\section{Resultados de la hidrofugación}

\section{Consumo}

En la Tabla 5 y Figura 3 se presentan los valores del consumo de los productos hidrofugantes y de la cantidad de materia seca tras la aplicación en condiciones idóneas y en presencia de sulfato de sodio y de agua.

En el tratamiento en óptimas condiciones del granito de Axeitos, el consumo de Tegosivin es bastante similar al de Siliker; sin embargo, la cantidad de materia seca de éste último es notablemente inferior, obteniéndose una relación consumo /materia seca elevadísima. En Baleante se encuentra un hecho explanation is that although the active material penetrated the stone and was retained, the polymerization reaction was not completed so that the pores were not covered sufficiently enough to reduce the porosity.

\section{Results of application of water repellents}

\section{Uptake}

The values recorded for the uptake of the water repellents and the dry polymer retained after application under optimum conditions and in the presence of sodium sulphate and of water are shown in Table 5 and Figure 3.

Following treatment of the AX granite under optimum conditions the uptake of Tegosivin was similar to that of Siliker. However, the amount of dry polymer remaining of the latter product was markedly less, the ratio of uptake/dry polymer being extremely high. The findings with the Baleante

TABLA 5 (TABLE 5)

Consumo (C: $\mathrm{g} / \mathrm{m}^{2}$ ), cantidad de Ḿateria Seca activa (MS: $\mathrm{g} / \mathrm{m}^{2}$ ) y relación Consumo/Materia Seca (C/MS) en la hidrofugación de Axeitos (AX) y Baleante (B) con sulfato de sodio, saturados en agua en un $50 \%$ y tras el tratamiento en condiciones óptimas.

(Uptake (U: $\left.\mathrm{g} / \mathrm{m}^{2}\right)$, amount of active Dry Polymer $\left(D P: \mathrm{g} / \mathrm{m}^{2}\right)$ and ratio of Uptake/Dry Polymer (U/DP) after water repellent treatment in Axietos $(A X)$ and Baleante $(B)$ granites, in the presence of sodium sulphate, $50 \%$ saturation with and after treatment under optimum conditions).

\begin{tabular}{|c|c|c|c|c|c|c|}
\hline & \multicolumn{3}{|c|}{ SILIKER } & \multicolumn{3}{|c|}{ TEGOSIVIN } \\
\hline \multicolumn{7}{|c|}{$\begin{array}{l}\text { TRATAMIENTO EN CONDICIONES ÓPTIMAS } \\
\text { (TREATMENT UNDER OPTIMUM CONDITIONS) }\end{array}$} \\
\hline & $\mathrm{C}(U)$ & $\operatorname{MS}(D P)$ & $\mathrm{C} / \mathrm{MS}(U / D P)$ & $\mathrm{C}(U)$ & $\operatorname{MS}(D P)$ & $\mathrm{C} / \mathrm{MS}(U / D P)$ \\
\hline $\mathrm{AX}$ & 73 & 0,1 & 730 & 92 & 19 & 4,84 \\
\hline B & 93 & 2,4 & 38 & 94 & 88 & 1,06 \\
\hline \multicolumn{7}{|c|}{$\begin{array}{l}\text { TRATAMIENTO EN PRESENCIA DE SULFATO DE SODIO } \\
\text { (TREATMENT IN THE PRESENCE OF SODIUM SULPHATE) }\end{array}$} \\
\hline & $\mathrm{C}(U)$ & $\mathrm{MS}(D P)$ & $\mathrm{C} / \mathrm{MS}(U / D P)$ & $\mathrm{C}(U)$ & MS $(D P)$ & $\mathrm{C} / \mathrm{MS}(U / D P)$ \\
\hline $\mathrm{AX}$ & 110 & 9 & 12 & 108 & 9 & 12 \\
\hline $\mathrm{B}$ & 185 & 35 & 5 & 160 & 30 & 5,3 \\
\hline \multicolumn{7}{|c|}{$\begin{array}{l}\text { TRATAMIENTO EN PRESENCIA DE 50\% DE HUMEDAD } \\
\text { (TREATMENT IN } 50 \% \text { SATURATION WITH WATER) }\end{array}$} \\
\hline & $\mathrm{C}(U)$ & $M S$ (DP) & C/MS (U/DP) & $\mathrm{C}(U)$ & $\mathrm{MS}(D P)$ & $\mathrm{C} / \mathrm{MS}(U / D P)$ \\
\hline $\mathrm{AX}$ & 74 & 69 & 1,07 & 192 & 116 & 1,65 \\
\hline B & 104 & 59 & 1,76 & 95 & 70 & 1,35 \\
\hline
\end{tabular}



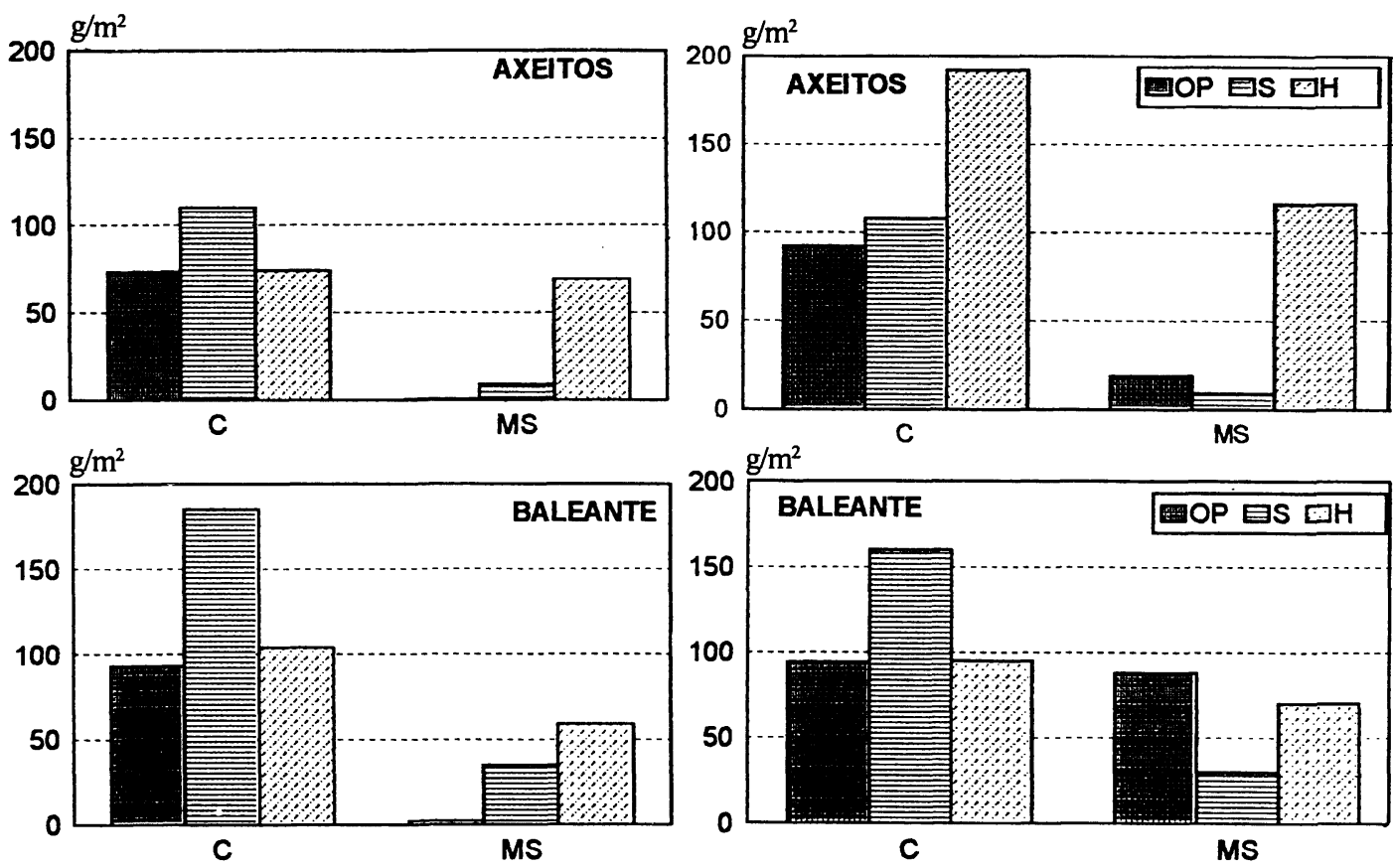

Figura 3.- Consumo y cantidad de materia seca activa en Axeitos (AX) y Baleante (B) hidrofurados en condiciones óptimas (OP), en presencia de sulfato de sodio $(\mathrm{S})$ y en presencia de agua $(\mathrm{H})$.

Figure 3.- Uptake and amount of dry polymer in Axeitos (AX) and Baleante (B) granites after water repellent treatment under optimum conditions (OP), in the presence of sodium sulphate ( $S 9$ and in the presence of water $(H)$.

similar: el consumo de ambos productos es el mismo pero permanece mayor cantidad de Tegovakon como materia seca tras el curado. También es llamativo el hecho de que en Axeitos tratado con Tegosivin la cantidad de materia seca sea cuatro veces más baja que en Baleante tratado con el mismo producto a pesar de que ambos granitos absorbieron la misma cantidad de producto.

En el tratamiento en presencia de sulfato de sodio, el consumo de ambos productos por los dos granitos se incrementa: en Axeitos el consumo de Tegosivin aumenta un $18 \%$ y el de Siliker un $50 \%$; en Baleante, el consumo de Tegosivin se incrementa en un $70 \%$ y el de Siliker en un $98 \%$. Las cantidades de materia seca se incrementan únicamente en el caso de Siliker, encontrándose relaciones consumo / materia seca notablemente inferiores a las del tratamiento en óptimas condiciones.

Las relaciones consumo/materia seca del producto Tegosivin en estas muestras son similares en ambos granitos, pero son superiores a las obtenidas en el tratamiento en condiciones idóneas, es decir, a pesar de un mayor consumo, las cantidades de materia seca de este producto no se incrementan proporcionalmente al mismo, siendo dos veces más bajas en el caso de Axeitos y cuatro veces más bajas en el caso de Baleante. granite were similar: the uptake of both products was the same but a higher level of Tegosivin was retained after drying. It is surprising that in the AX granite treated with Tegosivin, the level of dry polymer retained was four times lower than in the Baleante granite treated with the same product, even though both granites absorbed the same amount of product.

After treatment in the presence of sodium sulphate, the uptake of both products by the two granites increased: in the AX granite, the uptake of Tegosivin increased by $18 \%$ and that of Siliker by $50 \%$; in the Baleante granite, the uptake of Tegosivin increased by $70 \%$ and that of Siliker by $98 \%$. The level of dry polymer retained increased only in the case of Siliker, the ratio of uptake/dry polymer being considerably lower than with treatment under optimum conditions.

The ratios found for uptake/dry polymer for Tegosivin in these samples were similar in the two granites, but were higher than those found after application under optimum conditions. That is, despite there being a greater uptake of material, the amount of dry polymer retained did not increase proportionally, being two times lower with the AX granite and four times lower with the Baleante granite. 
En presencia de humedad, el producto Siliker es absorbido por ambos granitos en cantidades similares a las del tratamiento en óptimas condiciones. Sin embargo, las cantidades de materia seca son desproporcionadamente elevadas, obteniéndose relaciones consumo / materia seca muy bajas con respecto al tratamiento en óptimas condiciones.

En el tratamiento con Tegosivin se encuentra que, al contrario de lo que hasta ahora ocurría, Axeitos absorbe mayor cantidad de producto que Baleante, superando el valor correspondiente al tratamiento en condiciones óptimas y al tratamiento con Siliker. La materia seca obtenida también es elevada pero, en relación al consumo, más baja que el tratamiento con Siliker.

En Baleante el consumo de Tegosivin es ligeramente inferior que el de Siliker y similar al consumo del mismo producto en condiciones idóneas. La cantidad de materia seca con relación al consumo, sin embargo, es más alta que en el tratamiento con Siliker y, por el contrario, más baja que en el tratamiento en condiciones óptimas.

\section{Eficacia de los hidrofugantes}

En la Figura 4 se representan los valores del ángulo de contacto roca-agua de las probetas sin tratar, tratadas en condiciones óptimas de aplicación, y tratadas en presencia de agua y de sulfato de sodio.

En condiciones óptimas, el producto mas eficaz en la hidrofugación de la superficie de ambos granitos es Siliker; este hecho es llamativo, pues de ambos productos, es Siliker el que aparece en menor cantidad como materia seca.

En presencia de sulfato de sodio en las probetas, la eficacia de ambos productos es nula en ambos granitos (se obtienen valores de ángulo de contacto que no superan los $90^{\circ}$ ) excepto en lo que se refiere al producto Siliker aplicado al granito de Axeitos, cuya hidrorrepelencia oscila entre $90-100^{\circ}$.

La presencia de agua en las dos rocas graníticas no impide, por el contrario, la obtención de superficies con carácter hidrófugo, si bien, los valores de ángulo de contacto obtenidos no superan a aquéllos correspondientes al tratamiento en condiciones óptimas de aplicación; quizás la presencia del agua en la roca haya impedido el establecimiento de las uniones entre los grupos polares del sustrato y de los polímeros y, por tanto, la correcta orientación de los grupos apolares que es lo que da lugar al carácter hidrófobo de la superficie.

La eficacia de estas muestras no es concordante con sus correspondientes valores de materia seca, pues, según
In the presence of water, Siliker was absorbed by both granites in similar quantities to the treatment under optimum conditions. However, the amounts of dry polymer retained were disproportionately high, the ratio of uptake/dry polymer being very low compared to the treatment under optimum conditions.

With Tegosivin it was found, in contrast, that the AX granite absorbed more of the product than the Baleante granite, the amount being greater than the corresponding treatment under optimum conditions and in the Siliker treatment. The level of dry polymer remaining was also high, but in relation to the uptake it was lower than with Siliker.

The absorption of Tegosivin by the Baleante granite was slightly less than that of Siliker and similar to the uptake of the same under optimum conditions. The level of dry polymer remaining in relation to its uptake was, however, higher than with Siliker, and conversely lower than in the treatment under optimum conditions.

\section{Efficacy of water repellents}

The values of the rock-water contact angle for the untreated samples, samples treated under optimum conditions and those treated in the presence of sodium sulphate and of water are shown in Figure 4.

Under optimum conditions the most effective water repellent was Siliker; this was unexpected as of the two products it was Siliker that was retained to the least extent as dry polymer.

In the presence of sodium sulphate, the effectiveness of the two products was nil in both of the granite samples (values of $<90^{\circ}$ were obtained for the rockwater contact angle) except where Siliker was applied to the Axeitos granite whose water repellency ranged between $90-100^{\circ}$.

The presence of water did not impede the water repelling properties of the products in either of the granites, although the values of the rock-water contact angles obtained were not greater than those corresponding to the treatment under optimum conditions. Perhaps the presence of water in the stone had prevented binding of the polar groups in the substrate with those in the polymers thus preventing the correct orientation of the apolar groups of the polymer, which is what gives the surface its water repellent properties.

The effectiveness of these samples does not correspond with the values of dry material retained 

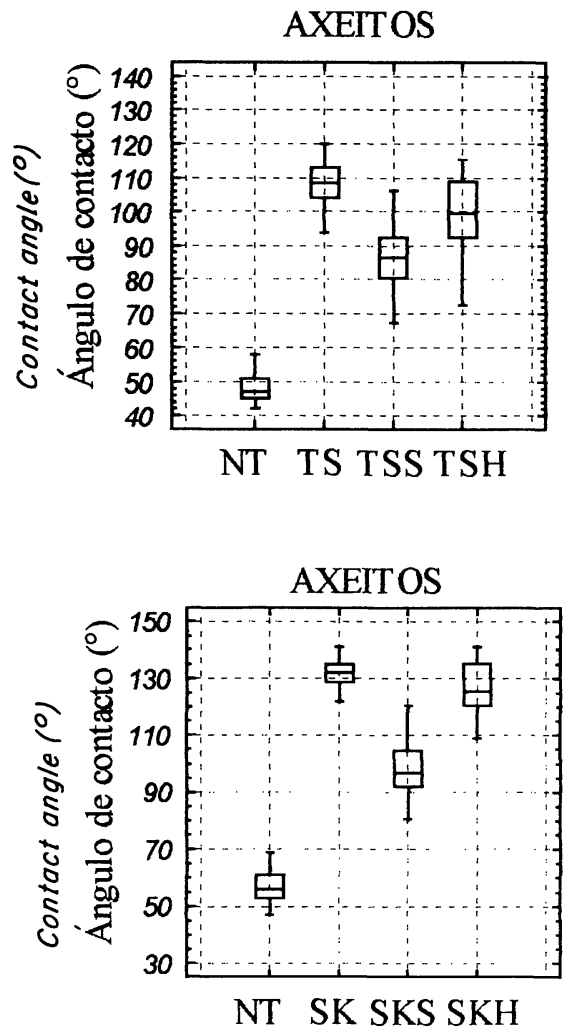

BALEANTE SANO

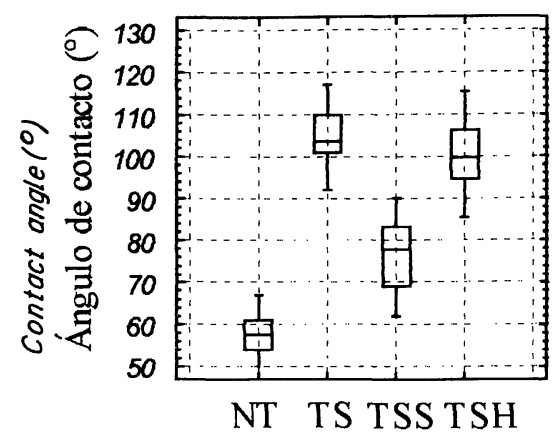

BALEANTE SANO

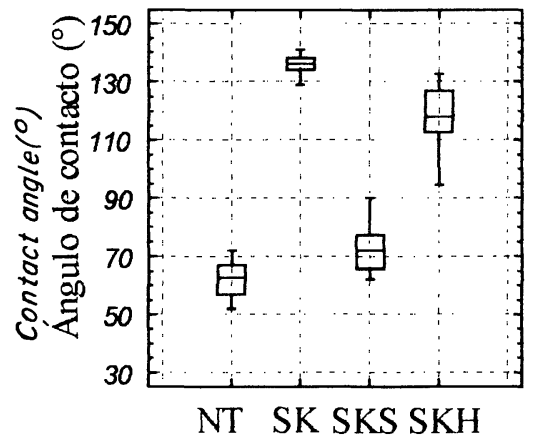

Figura 4.- Valores del ángulo de contacto roca-agua de las probetas de Axeitos (AX) y Baleante (B) sin tratar (NT), tratadas en condiciones óptimas (TS, Tegosivin; SK, Siliker), de probetas con sulfato de sodio (TSS, SKS) y de probetas con un grado de saturación en agua del $50 \%$ (TSH, SKH).

Figure 4.- Values of rock-water contact angle in samples of Axeitos (AX) and Baleante (B) without treatment (NT), treated under optimum conditions (TS, Tegosivin; SK, Siliker), in the presence of sodium sulphate (TSS, SKS) and with 50\% water saturation (TSH, SKH).

estos, se esperarían ángulos de contacto superiores a los obtenidos en el tratamiento normal. Este hecho puede estar indicando que durante la polimeración del producto y debido al carácter hidrófugo de éste, ha quedado atrapada cierta cantidad de agua en el interior de la masa rocosa, lo que pudo haber provocado una sobreestimación de la cantidad de materia seca activa.

\section{DISCUSIÓN Y CONCLUSIONES}

A partir de estos resultados son varias las consideraciones que se pueden establecer.

En primer lugar, se pone de manifiesto en la mayoría de los casos y, sobre todo en presencia de agua o de sales en la roca, la ausencia de relación directa entre consumo y materia seca y entre estos parámetros y la eficacia final conseguida, tanto de los consolidantes como de los hidrofugantes. De esta forma, creemos que la determinación de estos parámetros no es indicativa de la eficacia de un tratamiento, aunque es indudable que se deben cumplir las recomendaciones de consumo mínimo de los productos. A nuestro juicio, además de las características directamente from these, angles of contact greater than those found in the treatment under optimum conditions would be expected. This may indicate that, during the polymerization of the product and due to its water repellent properties, a certain amount of water remained trapped inside the structure of the stone leading to an overestimation of the amount of active dry polymer.

\section{DISCUSSION AND CONCLUSIONS}

From these results, various conclusions can be made.

Firstly, it is clear that in most cases, and in particular in the presence of water or salts, there was no direct relation between uptake and dry polymer remaining or between these and the final effectiveness of the treatment, for either consolidants or water repellents. Thus, we conclude that these parameters, uptake and dry polymer remaining, are not indicative of the effectiveness of a treatment, although the recommendations for minimum of uptake of the products should be followed when applying these treatments. The characteristics 
relacionadas con la naturaleza de los productos como la densidad, relación solvente-soluto, tipo de reacción de polimeración, existencia de catalizadores (Lewin y Whecler, 1985; Charola et al., 1985), las características intrínsecas de las rocas juegan un papel fundamental en la reacción de polimerización; así, aquellas características que gobiernan la cinética de transporte de fluidos a través del espacio poroso, como es el tipo de fisuración y la tortuosidad, influyen en la velocidad de evaporación del disolvente, en la distribución del producto en las fisuras y, por tanto, determinan una menor o mayor eficacia.

Consecuentemente, la presencia en el sistema fisural de agua o sales solubles va a constituir un factor modificador añadido.

Así, la presencia de sulfato de sodio afecta al tratamiento de consolidación en la medida en que disminuye notablemente el consumo y también, aunque no de manera proporcional, la materia seca. La presencia de la sal en estas muestras supone además un impedimento a la hora de evaluar de manera objetiva la eficacia del consolidante, ya que su presencia conduce a la determinación de un valor de porosidad más bajo del valor real. En este sentido, la estimación de la eficacia de un consolidante en sustratos que contienen sales en base a la disminución de la porosidad no es válida.

A nuestro juicio, la única manera de valorar la eficacia de un tratamiento de consolidación es evaluando la mejora en la resistencia mecánica de las rocas, pero esta determinación exige una cantidad importante de muestra que, en estudios de conservación de monumentos, supone generalmente un inconveniente insalvable. La valoración de la eficacia en estos casos también podría realizarse a través de ensayos de alteración artificial los cuales, aunque de manera indirecta y a más largo plazo, pueden dar información acerca de las mejoras que introducen los consolidantes en la resistencia de las rocas frente a la acción de agentes de deterioro físico, mejoras que constituyen, al fin y al cabo, el objetivo de un tratamiento de consolidación.

La presencia de agua en las rocas determina un menor consumo de los consolidantes, hecho que atribuimos al impedimento que ejerce el agua presente en los poros de las rocas a la penetración de los productos. En uno de los granitos, Axeitos, el agua no pareció impedir la reacción de polimerización del consolidante sino todo lo contrario, teniendo en cuenta la disminución de la porosidad en estas muestras. Sin embargo, el haber obtenido resultados diferentes en el otro granito estudiado no permite establecer generalizaciones en cuanto a que sea factible la aplicación de consolidantes en sustratos húmedos aunque sí indica claramente que las directly related to the nature of the product, such as. density, solvent -solute ratio, type of polymerization reaction and existence of catalysts are important to the overall treatment process (Lewin and Whecler, 1985; Charola et al., 1985). However, in our opinion, the intrinsic characteristics of the stone also play a fundametal role in the polymerization process. The characteristics that govern the kinetics of transport of fluids across the pores of the rock, such as type of fissuration and tortuosity influence the rate of evaporation of the solvent, the distribution of the product in the fissures and thus may determine the effectiveness of the treatment. As a consequence, the presence of water or salts in the fissures will modify the overall process.

Thus, the presence of sodium sulphate affects the consolidation treatment in that it significantly reduces uptake of the product and also the amount of dry polymer retained (although not proportionally). The presence of salt in the samples, furthermore, leads to underestimation of the porosity of the stone impeding the objective evaluation of the efficacy of the consolidant and thus making the open porosity measures invalid in these cases.

We believe that the only way to determine the efficiency of treatment with a consolidant is by evaluating the improvement of the physical resistance of the stone. This, however would require a large number of samples which in studies involving the conservation of historical monuments would be unrealistic. In these cases, the efficacy may also be measured by carrying out artificial weathering experiments. Although these take longer to carry out and give indirect results, they supply information on improvements in the resistance of stone to physical deterioration which after all, is the purpose of the consolidants.

The presence of water in the stone leads to a lower uptake of consolidants, presumably by physically preventing penetration of the product into the pores. In the Axeitos granite the presence of water does not appear to impede the polymerization reaction and in fact, does the contrary - taking into consideration the reduction in porosity of the samples. As different results were obtained for the other granite used, generalisations about the feasibility of application of consolidants to wet substrates cannot be made, although it is clear that characteristics of the substrate, such as the geometry of the fissural spaces 
características particulares del sustrato como la geometría del espacio fisural juegan un papel decisivo en la eficacia final del producto consolidante.

En la hidrofugación de sustratos con sulfato de sodio el consumo se incrementa de manera notable. A nuestro juicio, la presencia de cristales de sal en los poros de las rocas determina una mayor superficie a hidrofugar y por tanto una mayor absorción de producto .Por otra parte, la ausencia de eficacia, en contradicción con la elevada cantidad de materia seca, indican que la sal ha impedido una correcta reacción de los productos con las rocas.

En sustratos húmedos, la absorción de los productos hidrofugantes no se ve afectada como ocurre en presencia de sulfato de sodio, pero vuelve a encontrarse una cantidad excesiva de materia seca que no está en concordancia con el consumo, ya que éste es aproximadamente el mismo que en el tratamiento en condiciones óptimas. Sin embargo, el agua, a cuya presencia atribuimos la estimación errónea de la materia seca, no impide una correcta reacción entre el producto y el sustrato, ya que la eficacia obtenida es similar a la obtenida en condiciones óptimas de aplicación.

Se puede concluir por tanto que la consolidación e hidrofugación de rocas graníticas que poseen sulfato de sodio es desaconsejable debido a la total ineficacia encontrada. Hay que considerar también que la eficacia de estos productos puede verse todavía mas modificada si en el sustrato, además de esta sal, se encuentran otras, como ocurre en la mayoría de los monumentos graníticos afectados por procesos de cristalización de sales. En las intervenciones de hidrofugación en estos monumentos se debe ser, por otra parte, doblemente cautelosos, no sólo en relación con la eficacia de los productos sino también con los efectos negativos que la presencia del hidrofugante en este tipo de sustratos puede provocar (Rivas et al., 1998).

Las diferencias encontradas en cuanto a la eficacia de ambos tratamientos, consolidación e hidrofugación, entre ambos granitos y la enorme influencia sobre ella del estado en que se encuentra el sustrato a tratar señalan la necesidad de realizar en cada caso ensayos previos a su aplicación a los monumentos. play a decisive role in the final effectiveness of these products.

The application of water repellents to substrates containing sodium sulphate considerably increased uptake of the product. The presence of salt crystals in the stone appears to create a larger surface area to treat and thus leads to a greater uptake of product. On the other hand, the lack of efficacy contrasting with the high level of dry polymer retained suggests that the salt impedes the correct reaction of the products in the stone.

In wet substrates, absorption of the water repellents did not appear to be affected as in the presence of sodium sulphate, however there was once again a high level of dry polymer retained that was not in accordance with the uptake-this was similar to that found under optimum conditions. Athough the presence of water led to underestimation of the amount of dry polymer retained, it did not prevent the correct reaction between the product and the substrate occurring, as the effectiveness of the treatment was similar to that obtained under optimum conditions.

It can be concluded that the application of consolidation or water repellent treatments to granite substrates containing sodium sulphate is not advisable due to the lack of effectiveness of the treatment. It must also be considered that the efficacy of these products may be further modified by the presence of other salts as occurs in many granite buildings affected by salt crystallization. The use of water repellents on these buildings must be considered even more carefully, not only in relation to the efficacy of the products, but also because of the negative effects that may be brought about by their use on these substrates (Rivas et al., 1998).

The differences found in the effectiveness of the consolidation and water repellent treatments in the two granites and the huge influence of the condition of the substrate on the efficacy of these shows the need for pretreatment testing to be carried out on buildings and monuments.

\section{BIBLIOGRAFÍA}

(1) Casal, M.; Silva, B.; Delgado, J. (1989). Agents and forms of weathering in granitic rocks used in monuments. Proc. European Symp. Science, Technology and European Cultural Heritage, Bologna, 1989, N.S. Baer; C. Sabbioni; D.I. Sors (Ed.), 439-442.

(2) Charola, A. E.; Laurenzi-Tabasso, M.; Santamaría, U. (1985). The effect of water on the hidrofobic properties of an acrylic resiRroc V. Int. Symp. On Deterioration and Conservation of Stone. Lausanne (1985), vol. II, 697-708.

(3) Delgado, J. (1989). Causes, mechanisms and measurements of damage in monument stones Proc. Symp. Science, Technology and European Cultural Heritage, Bologna, 1989, N.S. Baer; C. Sabbioni; D.I. Sors (Ed.), 124-137 
(4) Ferreira, A.P. (1993). Conservaçao de pedras graníticas. Estudo da acçao de hidrofugos. Dissertaçao para a obtençao do grau de mestre en construcçao. Itto. Superior Tecnico. Universidade tecnica de Lisboa. 185 pp.

(5) Lewin, S.Z.; Whecler, G.E. (1985). Alcoxysilane chemistry and stone conservation. Proc. V. Int. Symp. On Deterioration and Conservation of Stone. Lausanne(1985), vol. II, 831-844.

(6) Rivas, T. (1997). Mecanismos de alteración de rocas graníticas utilizadas en la construcción de edificios antiguos de Galicia. Tesis Doctoral. Servicio de Publicaciones e Intercambio Científico. Universidad de Santiago. 368 pp.

(7) Rivas, T.; Prieto , B. ;Silva, B. (1998). Medida de la durabilidad de dos tratamientos de hidrofugación aplicados a rocas graníticas. Materiales de Construcción vol. 48, $\mathrm{n}^{\circ}$. 5-14 (1998).

(8) Reunion International des Laboratoires D'essais et de recherche sur les Matériaux et les constructions RILEM (1978). Crystallization by partial inmersion. Test V.2. Proc. Int. Symp. Deterioration and Conservation of Stone Monuments (UNESCO-RILEM), París, 1978.

(9) Reunion International des Laboratoires D'essais et de recherche sur les Matériaux et les constructions RILEM. Commision 25 PEM, protection et erosion des monuments (1980). Racommandations provisoires. Essais recommandés pour mesures l'alteration des pierres et évaluer l'efficatité des méthodes de traitment. Porosity accesible to water. Test. II.6.

(10) Silva, B.; Rivas, T.; Prieto; B.; Delgado, J. (1996 a). A comparison of the mechanims of plaque formation and sand disagreggation in granitic historic buildings. En Degradation and Conservation of Granitic Rocks in Monuments. M.A. Vicente; J. Delgado; J. Acevedo (Eds.) Europeam Commision DG XII (Publis.) Report n5, 269-274.

(11) Silva, B.; Rivas, T.; Prieto; B. (1996 b). Relation between type of soluble salt and decay forms in granitic coastal churches in Galicia (NW Spain). In European Commision Research Workshop Origin, Mechanisms and Effects of Salts on Degradation of Monuments in Marine and Continental Environments. March 1996, Bari (Italy), Zezza, F. (Ed.). DGXII Protection and Conservation of The European Cultural Heritage, Research Report n ${ }^{\circ}, 181-190$.

\section{publicaciones del IETCC/CSIC}

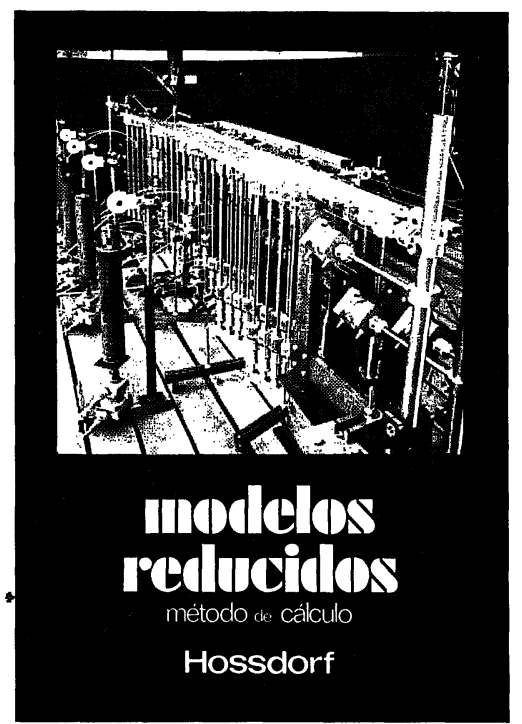

Modelos reducidos. Método de cálculo

H. Hossdorf, Ingeniero Civil

La técnica de los ensayos en modelos reducidos de estructuras sufre hoy dia una decisiva metamorfosis. Hasta hace poco era un medio más bien de artesania, que no siempre era tomado en serio por los academicos teorizantes para comprender el comportamiento resistente de las estructuras complejas $y$ al que se acudió las más de las veces, como a un ultimo remedio debido a sus indiscutibles insuficien cias. Sin embargo, en poco tiempo y gracias a su conexion con los ordenadores digitales, se ha transformado en un instrumento cientificamente valioso, que no puede quedar a un ta diaria del Ingeniero Proyectista.

Un volumen encuadernado en cartoné plastificado con lomo de tela de $17 \times 24 \mathrm{~cm}$, compuesto de 250 páginas, 158 figuras y fotografias.

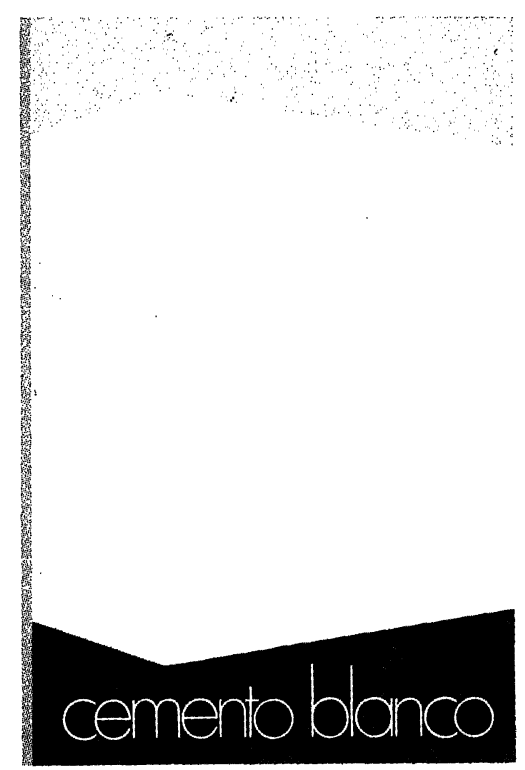

Cemento blanco

Julián Rezola

Ingeniero Quimico Dipl. I. Q. S.

Sabido es que existe una extensa y documentada bibliografia sobre el cemento gris: en cambio, no puede decirse lo mismo acerca del cemento portland blanco, ya que los escritos existentes se refieren tan sólo a algunas peculiaridades que le distinguen de aquél.

El autor nos ofrece sus profundos conocimientos $y$ su larga experiencia tanto en laboratorio como y su larga ex

La parte descriptiva del libro se complementa con gráficos, diagramas y fotografias de gran utilidad, destinados a conseguir la aplicación apropiada de este aglomerante.

Un volumen encuadernado en cartoné policerado, do $17,4 \times 24,3 \mathrm{~cm}$, compuesto de 395 páginas

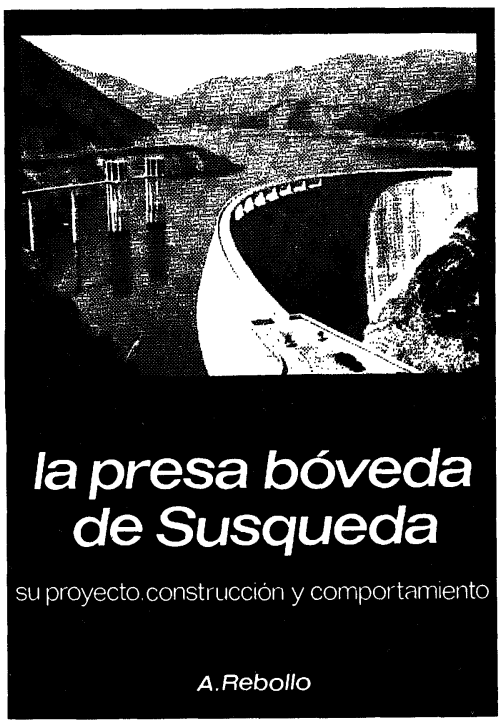

La presa bóveda de Susqueda

A. Rebollo,

Dr. Ingeniero de Caminos

El esfuerzo del constructor de presas se situa, por su pretensión de perennidad, a contracorriente de las tendencias de la civilización actual, caracte rizada por lo fungible. Pueden evocarse las 10.000 grandes. presas en funcionamiento o en construcción que están envejeciendo y reclaman los cuidados gerontológicos para mantener y perfeccionar su servicio y garantizar su inalienable pretensión de perennidad. En la medida en que todas nuevas obras, grandes o pequeñas, son portadoras de riesgos ecologicos $y$, a veces, catastróficos, que aumentan con el envejecimiento, la gerontologia de las presas es todo un emplazo. La acción adelantada de Arturo Rebollo en este terreno marca un camino a seguir para todos los que aman su propia obra con la devoción paternal que èl ha puesto en Susqueda.

Un volumen encuadernado en cartonè plastificado con lomo de tela, de $18 、 24,5 \mathrm{~cm}$, compuesto de 408 páginas, 330 figuras y fotografias y 39 tablas. 